\title{
INFLUENCE OF THE BASIC TO CULTIVATION OF THE SOIL, TERM AND A WAY OF SOWING ON ELEMENTS OF FERTILITY OF THE SOIL AND PRODUCTIVITY OF COLZA WINTER
}

\section{ВПЛИВ ОСНОВНОГО ОБРОБІТКУ ГРУНТУ, СТРОКУ ТА СПОСОБУ СІВБИ НА ЕЛЕМЕНТИ РОДЮЧОСТІ ГРУНТУ І ПРОДУКТИВНІСТЬ РІПАКУ ОЗИМОГО}

\section{Tetiana Baklanova ${ }^{1}$ \\ Valentina Gamayunova ${ }^{2}$}

DOI: https://doi.org/10.30525/978-9934-588-15-0-129

Abstract. The article highlights the importance of soil cultivation in the modern period of management, shows the influence of different methods and depth of processing on the moisture content in the soil, weeds and crop yields, in particular, the value of the two main methods of soil cultivation relative to their influence factor on the yield of winter rape. The importance of soil fertility and the content of organic matter in it and the provision of plants with moisture and water-physical properties of the soil, which is especially important when climatic conditions change, is substantiated. These indicators are significantly influenced by measures of basic tillage, which is also covered in the article. The study was conducted during 2012-2015 on ordinary Chernozem to determine the measures of basic tillage. The culture was sown on the background of traditional plowing at $25-27 \mathrm{~cm}$ and disking, which was carried out to a depth of $12-14 \mathrm{~cm}$, depending on the method of basic tillage and its depth, the main agrophysical properties of the soil, in particular, the density of addition, the content of mobile nutrients during the vegetation of winter rape plants, were investigated. It is determined that the studied factors, taken for study, significantly affect the availability and distribution in the soil layers of mobile compounds of nitrogen, phospho-

\footnotetext{
${ }^{1}$ Candidate of Agricultural Sciences, Associate Professor, Associate Professor of the Department of Mechanization and Life Safety, Kherson State Agrarian University, Ukraine ${ }^{2}$ Doctor of Agricultural Sciences, Professor, Head of the Department of Agriculture, Geodesy and Land Management, Mykolaiv National Agrarian University, Ukraine

(C) Tetiana Baklanova, Valentina Gamayunova
} 
rus, potassium. The main water-physical and agrochemical properties of the soil, in turn, affect the level of yield of winter rape seeds and individual indicators of its quality. Based on the background of two methods of basic tillage, the optimal sowing time and row spacing were studied in the cultivation of winter rape. Under the influence of all factors and weather conditions of the growing season, the yield of seeds changed. It is established that the productivity of the studied culture is most affected by the sowing period and less it depends on the tillage and row spacing. These factors affected the content of fat and protein in winter rape seeds and their conditional collection (output) per unit area. The highest protein content in the seeds and its oiliness, as well as their conditional fee for sowing in the i decade of September with a width of $15 \mathrm{~cm}$ row spacing. Later planting and increasing the row spacing to 30 and $60 \mathrm{~cm}$ led to a decrease in both the yield level and the deterioration of the main indicators of the quality of winter rape seeds.

\section{1. Ветуп}

Відомо, що в останні роки родючість основних типів грунтів України потерпає змін, що пов'язані як з особливостями господарювання, добором елементів технології у вирощуванні сільськогосподарських культур, застосуванням добрив, зокрема недостатнім внесенням органічних, так і зі зміною клімату. Зокрема, збіднення грунтів на органічну речовину дуже сильно послаблює їх здатність накопичувати, утримувати вологу в грунті та ощадливе їі використання рослинами. I навпаки, якщо органіки міститься достатньо, волога утримується в грунті та ефективно використовується рослинами на формування врожаю, а не на непродуктивні втрати через надмірне випаровування [1]. Залежно від умов, що склалися нині зі станом родючості грунтів і в першу чергу з їх структурно-агрегатним складом та здатністю поглинати й утримувати вологу, чільне місце посідає обробіток грунту, добір культур у сівозміні і головне систематичне поповнення грунту органічною речовиною [2]. За оптимізації усіх зазначених факторів, процеси деградації посилюватись не будуть, а навпаки, основні показники родючості залишаться на постійному рівні, стабільними у т.ч. не буде зменшуватись вміст гумусу, основних елементів живлення тощо. Основний обробіток грунту при цьому за впливом на елементи родючості грунту та продуктивність сільськогосподарських культур посідає 
чільне місце, його дослідження $є$ виключно актуальними, а зі зміною кліматичних умов практично першочерговими. Проте в останні роки немає чіткої думки вчених щодо ефективності добору кращого способу основного обробітку грунту як у системі сівозмін, так і під окремі сільськогосподарські культури. Окремі дослідники вважають за доцільне переходити до більш мілких (поверхневих) способів обробітку грунту, інші пропонують проводити традиційні системи обробітку грунту, прийняті й рекомендовані для зони, а більшість дослідників вважають найбільш оптимальним використовувати диференційовану різноглибинну систему основного обробітку грунту за чергування глибоких i мілких способів грунту залежно від сільськогосподарської культури, стану грунту і погодних умов року. Тобто у теперішній час відсутня єдина думка щодо правильності добору способу і технічного знаряддя для того чи іншого заходу обробітку грунту. До того ж раніше за дотримання науково обгрунтованого чергування сільськогосподарських культур у сівозміні, за високої та середньої забезпеченості грунту органічною речовиною і NPK, на обробіток грунту в структурі сформованого рівня врожаю припадало лише 4-5 \% впливу від усіх факторів, а за сучасних умов ця частка істотно зростає й особливо за посилення посушливості.

\section{2. Властивості грунту під впливом заходів його обробітку}

Сприятливі умови для життєдіяльності рослин створюються за оптимізації усіх факторів у т.ч. й за створення відповідної щільності грунту, яка в свою чергу впливає на поживний, водний і повітряний режими, тобто від щільності зложення значною мірою залежить забезпеченість рослин вологою, елементами живлення та повітрям і в кінцевому підсумку рівень їх урожайності.

В останні роки в землеробстві швидко зростає енергоозброєність сільського господарства, що створює необмежені можливості для інтенсифікації та оптимізації основних заходів обробітку грунту. Проте досвід і практика показують, що в багатьох випадках з посиленням інтенсивності обробітку все частіше проявляються негативні наслідки. Перш за все істотно зростають грошові витрати на його виконання, (адже в структурі витрат на вирощування обробіток грунту займає вагоме місце), які не завжди супроводжуються підвищенням урожай- 
ності, до того ж під впливом окремих заходів обробітку пришвидшується і посилюється мінералізація гумусу, грунт може розпилюватись, зменшується його стійкість проти ерозії. Відомо, що кожен прохід трактора і грунтообробних знарядь призводить до переущільнення грунту, що негативно впливає на якість наступних обробітків та врожайність сільськогосподарських культур [3].

За даними ряду авторів, визначено, що тривале застосування мілкої оранки, безполицевого обробітку і особливо дискування, сприяє диференціації орного шару грунту за твердістю і щільністю. Як правило, ці показники в шарі грунту 0-10 см зменшуються, а у глибших шарах 10-20 і 20-30 см, порівняно з оранкою збільшуються.

Теоретичною основою мінімізації обробітку слугують досягнення в галузі агрофізики грунту. У багатьох випадках рівноважна щільність не виходить за межі оптимальної, а розпушування грунту не завжди сприяє збереженню в ньому вологи [4; 5]. Загально визнаною є думка, що надмірна щільність погіршує водний і повітряний режими грунту, стає механічною перешкодою на шляху розвитку кореневої системи рослин, що особливо сильно проявляється за зростання посушливості клімату.

Набагато раніше проведено багато досліджень щодо вивчення реакції сільськогосподарських культур на щільність орного шару грунту. І.Б. Ревут зі співавторами узагальнюючи літературний матеріал, роблять висновок про те, що реакція рослин на щільність будови грунту носить зональний характер [6].

В останні десятиліття в більшості регіонів України все частіше 3 метою економії ресурсів різні заходи у т.ч. й основний обробіток грунту спрямовують у сторону мінімалізації, враховуючи при цьому грунтово-кліматичні умови, кількість післяжнивно-кореневих залишків попередньої культури, фітосанітарний стан посіву тощо [7; 8]. В окремих випадках науковці рекомендують використовувати навіть мульчувальний обробіток грунту, який залежно від умов може бути ефективним [9].

3 метою зменшення енергетичних витрат досліджують і пропонують використовувати під різні сільськогосподарські культури замість традиційного полицевого безполицевий за різної глибини, пропонують поєднувати поверхневі мілкі, звичайні та глибокі полицеві і безполицеві способи обробітку грунту. Вказані способи звичайно ж мають 
як певні переваги, так і недоліки, адже якість обробітку залежить від багатьох факторів, і перш за все стану грунту (рівня його зволоження, вмісту органічної речовини) та конкретних кліматичних умов $[10 ; 11$; 12]. Ряд дослідників, провівши тривале вивчення і порівняння щодо ефективності заходів основного обробітку грунту, дійшли висновку про необхідність його диференціації, зокрема, оптимальною у сприятливі за зволоженням роки визначено оранку, а за посушливих умов краще застосовувати поверхневий обробіток грунту [8; 13; 14].

Урожайність ріпака залежно від факторів вирощування. За традиційних технологій вирощування ріпаку озимого, рівень урожайності коливається в досить широких межах. У середньому, по Україні врожайність цісї культури становить 1,73 т/га, а в окремих господарствах 3,0-3,5 т/га. Хоча для Європи врожайність ріпаку в 3,5-4,0 т/га є звичайною.

Вплив основного обробітку грунту на врожайність польових культур носить різнобічний, складний характер. Обумовлюється це багатьма агрофізичними показниками грунту, біологічними особливостями сорту чи гібриду, агротехнічними умовами вирощування культур про що ми зазначали.

У науковій літературі немає єдиної думки щодо впливу різних систем основного обробітку грунту на врожайність насіння ріпаку озимого. У вчених і виробничників існує декілька думок. Більшість 3 них дотримуються думки, що кращим є традиційний обробіток грунту - оранка, разом $з$ тим в останні роки зростає кількість прихильників безполицевого обробітку, який, порівняно з оранкою $є$ менш енерговитратним.

Як відомо з наукової літератури, традиційна технологія вирощування ріпаку базується на оранці, завдяки чому забезпечується безперешкодний розвиток стрижневого кореня рослини.

До того ж відомо, що на початкових фазах росту і розвитку ріпак не витримує конкуренції з бур'янами. Забур'яненість посіву в осінню вегетацію призводить до надмірного виносу точки росту над поверхнею грунту, слабкішого розвитку кореневої системи, що збільшує ризик вимерзання ріпаку озимого і призводить у подальшому до формування низької врожайності таких посівів [15; 16]. Встановлено, що за умов оптимізації живлення та недопущення зрідження посівів уміст цукрів у коренях рослин ріпаку накопичується більш високим та забезпечує сприятливу перезимівлю [17]. 
Часто складні кліматичні умови, в першу чергу недостатня кількість вологи на період підготовки грунту під сівбу ріпаку озимого та збільшення посівних площ під цією культурою, вимагають добору у застосуванні різних систем мінімального, так званого безполицевого, обробітку грунту.

Як відомо, ріпак озимий вважають холодостійкою культурою. Він здатен витримувати температури до $-21^{\circ} \mathrm{C}$, а за наявності снігового покриву 5-10 см деякі сорти не гинуть навіть при $\mathrm{t}-31^{\circ} \mathrm{C}$. Дослідниками встановлено, що рослини ранніх строків сівби часто переростають в осінній період і за зиму вимерзають за відсутності або при незначному сніговому покриві, а пізніх - не встигають достатньо розвинутися i також гинуть. Саме недотримання оптимального строку сівби призводить до недобору 30-50 \% урожаю [18]. Одним, із елементів технології вирощування, який здатен забезпечити високу продуктивність агроценозів ріпаку озимого, є оптимальний строк сівби. Це набуває актуальності в останні роки за зміни основних показників родючості грунтів, кліматичних умов і зростання посушливості.

Наведений аналіз щодо ефективності обробітку грунту пересвідчує нас, що єдиної думки і рекомендації застосування конкретного заходу його під певну сільськогосподарську культуру, зокрема і ріпак озимий, не існує. Необхідно вивчати вплив існуючих способів обробітку грунту для конкретної зони, умов року вирощування, виду культури, характеристики показників родючості грунту тощо з тим, щоб його удосконалити і визначитись, якому заходу чи системі обробітку за конкретних умов надати перевагу. Це іще раз пересвідчує актуальність напряму досліджень.

\section{3. Матеріали і методи проведення досліджень}

Мета досліджень полягала у визначенні більш ефективного способу основного обробітку грунту під ріпак озимий - традиційної оранки на 25-27 см або дискування на 12-14 см, його вплив на щільність зложення чорнозему звичайного, забезпеченість грунту рухомими елементами живлення, вплив на формування урожайності і якості насіння культури у роки вирощування.

Зважаючи, що спосіб основного обробітку грунту впливає на основні агрофізичні показники й перш за все накопичення вологи в 
грунті та у зв'язку зі зміною кліматичних умов, важливим елементом у технології вирощування ріпаку озимого $є$ визначення найбільш оптимального строку сівби і ширини міжрядь. Ці фактори ми також включили в програму дослідження.

Дослідженнями передбачали встановити вплив факторів обробітку грунту на щільність зложення чорнозему, вміст у ньому рухомих NPK, рівень урожайності та якості насіння залежно від розробки та удосконалення елементів технології вирощування, зокрема від способу обробітку грунту під ріпак озимий сорту Чемпіон України в умовах південного Лісостепу України з метою отримання високої врожайності та якісного насіння за позитивного впливу на щільність грунту й окремі показники його родючості. Польові досліди проводили на чорноземі звичайному згідно методики польових дослідів та методичних рекомендацій.

У трифакторному польовому досліді вивчали вплив способу основного обробітку грунту на окремі показники його родючості, ріст, розвиток і формування продуктивності рослин ріпаку озимого залежно від обробітку грунту, а також інших важливих елементів технології - строку і способу сівби, які зі зміною клімату потребують уточнення та удосконалення.

Дослід закладено методом розщеплених ділянок у відповідності 3 методикою польових дослідів 3 вивчення агротехнічних прийомів вирощування сільськогосподарських культур. Повторність досліду чотириразова. Площа посівної ділянки $-80 \mathrm{~m}^{2}$, облікової - $50 \mathrm{~m}^{2}$. У досліді висівали районований сорт ріпаку озимого Чемпіон України. Попередником його була пшениця озима.

\section{4. Зміна властивостей грунту під впливом способу і глибини обробітку}

Використовуючи щільність складення як діагностичний показник при застосуванні того чи іншого способу обробітку грунту рекомендується зіставляти рівноважну щільність для конкретного типу грунту з оптимальними іiі параметрами для рослин. Невідповідність цих величин вказує на необхідність добору заходу обробітку грунту, прийоми і способи якого повинні визначатись біологічними особливостями вирощуваної культури.

Нами були проведені визначення щільності складення орного шару за різних прийомів основного обробітку грунту в основні періоди вегетації ріпаку озимого, результати яких наведені в таблиці 1. 
Щільність складення 0-30 см шару грунту після збирання попере-

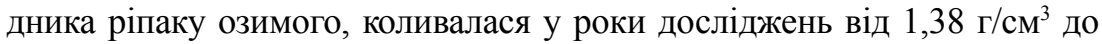

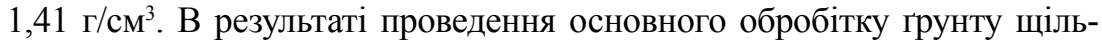
ність складення всіх варіантів досліду знизилася, однак зміна цього показника більшою мірою залежала від способу основного обробітку та його глибини. Більш рихле складення грунту забезпечувала оранка, яку проводили на 25-27 см. У середньому щільність складення 0-30 см

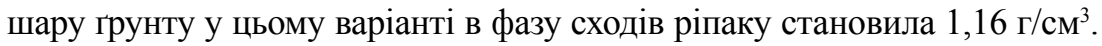
На ділянках, оброблених дисковою бороною, на глибину 12-14 см, вона була більшою порівняно з варіантами оранки на 0,12 г/ $\mathrm{cm}^{3}$.

Таблиця 1

Динаміка щільності складення грунту на посівах ріпаку озимого залежно від способу його обробітку, г/см³ (середнс за 2013-2015 рр.)

\begin{tabular}{|c|c|c|}
\hline \multirow{2}{*}{ Шар грунту, см } & \multicolumn{2}{|c|}{ Обробіток грунту } \\
\hline & оранка & дискування \\
\hline \multicolumn{3}{|c|}{ Сходи } \\
\hline $0-10$ & 1,05 & 1,08 \\
\hline $10-20$ & 1,16 & 1,34 \\
\hline $20-30$ & 1,28 & 1,41 \\
\hline $0-30$ & 1,16 & 1,28 \\
\hline \multicolumn{3}{|c|}{ Стеблування } \\
\hline $0-10$ & 1,12 & 1,24 \\
\hline $10-20$ & 1,30 & 1,39 \\
\hline $20-30$ & 1,35 & 1,44 \\
\hline $0-30$ & 1,26 & 1,36 \\
\hline \multicolumn{3}{|c|}{ Цвітіння } \\
\hline $0-10$ & 1,24 & 1,25 \\
\hline $10-20$ & 1,39 & 1,41 \\
\hline $20-30$ & 1,41 & 1,44 \\
\hline $0-30$ & 1,35 & 1,37 \\
\hline \multicolumn{3}{|c|}{ Повна стиглість насіння } \\
\hline $0-10$ & 1,14 & 1,17 \\
\hline $10-20$ & 1,23 & 1,40 \\
\hline $20-30$ & 1,26 & 1,44 \\
\hline $0-30$ & 1,21 & 1,34 \\
\hline
\end{tabular}


Аналогічні результати отримали й інші автори, що присвятили свої дослідження заходам основного обробітку грунту та визначенню цього показника [19].

Під впливом осінньо-зимових опадів спостерігали ущільнення грунту. Причому, незалежно від прийому основного обробітку в більшій мірі до ущільнення мав схильність верхній (0-10 см) шар грунту. У середньому, 0-30 см шар до фази стеблування у варіанті з оранкою ущільнився на 0,1 г/см3, а за дискування на 0,08 г/см3. Нашими дослідженнями встановлено, що орний шар грунту істотніше ущільнюється в осінньо-зимовий і ранньовесняний періоди.

Незначне ущільнення грунту в усіх варіантах досліду спостерігали до фази цвітіння ріпаку озимого, що частково відбувалося й під впливом атмосферних опадів. У цей період спостерігали деяке нівелювання відмінностей у щільності складення грунту за варіантами досліду.

Таким чином, проведення оранки на глибину 25-27 см під посіви ріпаку озимого сприяє зменшенню щільності складення грунту, внаслідок чого покращує умови для життєдіяльності рослин - сприяє оптимальному розвитку кореневої системи, покращує водний, поживний та повітряний режими грунту.

Основним джерелом елементів живлення для рослин $є$ грунт. Рівень родючості грунту вважають визначальним фактором одержання високих і сталих урожаїв сільськогосподарських культур. Це явище не $є$ постійним, у деяких випадках воно динамічне, а в оброблюваних грунтах ця динаміка безперервна. Численні наукові дані щодо впливу тривалого застосування різних систем основного обробітку на поживний режим грунту є суперечливими.

Порівняно зі щорічною оранкою довготривалий безполицевий обробіток призводить до збільшення вмісту рухомого фосфору та обмінного калію у верхній частині орного шару грунту і значного їх зменшення в нижній [20].

3 метою усунення диференціації орного шару грунту за родючістю та підвищення його мікробіологічної активності ряд дослідників дійшли висновку про доцільність періодичного чергування полицевих і безполицевих обробітків грунту [21;22].

Ріпак озимий здатен розвивати велику кореневу систему та накопичувати значну надземну біомасу, тому він засвоює з грунту багато 
елементів живлення. Для створення однієї тонни насіння він виносить із грунту: азоту - 45-80 кг, фосфору - 18-40 кг, калію - 25-100 кг, кальцію - 30-150 кг, магнію - 5-15 кг, сірки - 30-45 кг [23].

Поживний режим грунту багато в чому залежить від способу основного обробітку грунту. Оранка порівняно $з$ дискуванням призводить до значного посилення мінералізації органічної речовини і збільшує ефективність використання елементів мінерального живлення [24].

Разом 3 тим, при проведенні основного обробітку грунту з обертом пласта, через активну нітрифікацію і подальшу денітрифікацію, відбувається втрата азоту [10]. За безвідвальних обробітків цей процес відбувається в анаеробних умовах, що сприяє збагаченню грунту елементами живлення.

Наші дослідження підтверджують вплив прийомів основного обробітку грунту під ріпак озимий на його поживний режим.

Проведеними дослідженнями в умовах природного зволоження, нами встановлено, що вміст нітратів у грунті змінювався на протязі вегетаційного періоду ріпаку озимого (табл. 2).

Таблиця 2

Вміст нітратів у грунті під посівами ріпаку озимого, мг/кг грунту (середне за 2013-2015 рр.)

\begin{tabular}{|c|c|c|c|c|}
\hline \multirow{2}{*}{$\begin{array}{c}\text { Шар грунту, } \\
\text { см }\end{array}$} & \multicolumn{5}{|c|}{ Фаза росту та розвитку рослин } \\
\cline { 2 - 5 } & сходи* & $\begin{array}{c}\text { весняна } \\
\text { розетка }\end{array}$ & цвітіння & $\begin{array}{c}\text { молочна стиглість } \\
\text { насіння }\end{array}$ \\
\hline \multicolumn{5}{|c|}{ Дискування на $12-14$ см } \\
\hline $0-30$ & 2,29 & 28,6 & 11,1 & 15,7 \\
\hline $30-50$ & 1,12 & 14,7 & 4,7 & 7,1 \\
\hline $0-50$ & 1,82 & 23,0 & 8,5 & 12,3 \\
\hline \multicolumn{5}{|c|}{ Оранка на $25-27$ см } \\
\hline $0-30$ & 2,34 & 30,8 & 2,7 & 16,1 \\
\hline $30-50$ & 1,09 & 15,3 & 5,5 & 7,6 \\
\hline $0-50$ & 1,84 & 24,6 & 9,8 & 12,7 \\
\hline
\end{tabular}

*середне за 2012-2014 pp.

Визначено, що незалежно від прийому основного обробітку грунту, максимальна кількість нітратів містилася у фазу утворення весняної 
розетки. У подальшому, у фазу цвітіння, спостерігали зниження вмісту нітратів у грунті, що співпадає з періодом максимального споживання азоту рослинами ріпаку. У фазу молочної стиглості насіння через відмирання дрібних коренів і часткової їх мінералізації відбувається незначне підвищення вмісту нітратів у орному і підорному шарах грунту 0-50 см.

Проведення оранки сприяло посиленню процесів нітрифікації і супроводжувалося більшим накопиченням нітратів у шарі грунту 0-50 см порівняно з дискуванням. У цьому варіанті досліду їх вміст у період вегетації рослин ріпаку озимого був на 0,02-0,16 мг/100 г грунту більшим порівняно $з$ посівами, де проводили дискування.

Пояснюється це тим, що у фазу весняної розетки більша частина нітратів витрачалась на відновлення відмерлої вегетативної маси, через що їх вміст у грунті зменшувався. У фазу цвітіння рослини формували значну надземну масу, що й спричинило відповідно більше використання нітратів із грунту. До кінця вегетації споживання азоту рослинами знижується і вміст нітратів у грунті за варіантами досліду вирівнюється.

У рослинах фосфору міститься значно менше, ніж азоту. Однак забезпеченість рослин цим елементом живлення потребує не меншої турботи, ніж азотом. Особливо важливою обставиною, яка ускладнює живлення рослин фосфором, є низька його розчинність та рухомість у грунті. Фосфор за внесення в грунт у формі розчинних мінеральних добрив, швидко переходить в слабко- і важкорозчинні форми за взаємодії, перш за все, з карбонатами кальцію, утворюючи тризаміщений фосфат кальцію, який слабко розчиняється за нейтрального середовища грунтового розчину.

Доступність рослинам фосфатів грунту залежить, перш за все, від оптимізації умов для мікробіологічної активності грунту, шляхом створення відповідної аерації і підвищення вологозабезпеченості внаслідок структуроутворення і розпушування грунту, внесення органічних добрив. Особливість забезпечення рослин фосфором за різних способів обробітку грунту пов'язана з перерозподілом рухомих фосфатів у межах шару, що обробляється.

Акумуляція рухомого фосфору в 0-10 см шарі пов'язана з локалізацією в ньому добрив, а також з тим, що фосфати контактують з меншим об'ємом грунту і тому менше фіксуються абсорбуючим комплексом [21]. 
Гетерогенність орного шару грунту у відношенні до фосфору вважають позитивним явищем, тому що за цього покращуються умови живлення, особливо на початку вегетації рослин, коли з верхнього шару рослини використовують у 10 разів більше фосфору, ніж 3 нижнього шару грунту [22].

Нашими дослідженнями встановлено, що на початку вегетації ріпаку озимого в шарі грунту 0-50 см більша кількість рухомого фосфору містилася за проведення оранки на 25-27 см (табл. 3).

У варіантах з проведенням дискування грунту на 12-14 см цей показник був меншим на 1,72 мг/кг грунту. У подальшій вегетації відмінності у вмісті рухомого фосфору в грунті за обох способів його обробітку вирівнюються і вже у фазу молочної стиглості насіння вони були неістотними.

Таблиця 3

Вміст рухомого фосфору у грунті під посівами ріпаку озимого, мг/кГ грунту (середне за 2013-2015 рр.)

\begin{tabular}{|c|c|c|}
\hline \multirow{2}{*}{ Шар грунту, см } & \multicolumn{2}{|c|}{ Фаза росту та розвитку рослин } \\
\cline { 2 - 3 } & Сходи & $\begin{array}{c}\text { Молочна стиглість } \\
\text { насіння }\end{array}$ \\
\hline \multicolumn{3}{|c|}{ Дискування на $12-14 \mathrm{~cm}$} \\
\hline $0-30$ & 47,2 & 39,9 \\
\hline $30-50$ & 21,8 & 18,2 \\
\hline $0-50$ & 33,9 & 29,0 \\
\hline \multicolumn{3}{|c|}{ Оранка на $25-27$ см } \\
\hline $0-30$ & 42,4 & 33,9 \\
\hline $30-50$ & 38,7 & 29,0 \\
\hline $0-50$ & 41,1 & 31,5 \\
\hline
\end{tabular}

Найбільшим зниження вмісту рухомих фосфатів упродовж вегетації було визначене в грунті варіанта 3 проведенням оранки - 9,6 мг/кг грунту, що лише на 0,05 мг/кг грунту перевищило варіант з дискуванням.

\section{5. Вплив досліджуваних факторів формування врожаю і якості насіння ріпаку озимого}

Проведені нами дослідження 3 визначення рівня врожайності насіння свідчать, що в середньому за три роки посіви ріпаку озимого 
за поверхневого обробітку грунту (дискування на 12-14 см) за рівнем урожайності поступались посівам, під які проводили оранку на 25-27 см: зібрано 3,2 т/га та 3,4 т/га відповідно.

Нами визначено, що врожайність насіння ріпаку істотно залежала i змінювалась під впливом погодних умов, що склались у роки досліджень. Дискування на глибину 12-14 см призводило до ії зниження у сухі роки, а у вологі роки вона формується на такому ж рівні як і за проведення типового основного обробітку грунту - оранки. Так, у сприятливому за зволоженістю 2013 р. перевагу мали посіви по фону безполицевого обробітку грунту, за якого врожайність насіння склала 3,3 т/га. Проте у 2014 та 2015 рр. у варіантах $з$ оранкою на 25-27 см порівняно $з$ дискуванням на 12-14 см посіви ріпаку озимого сформували врожайність насіння на 12,9-22,6\% вищу.

Оранка на глибину 25-27 см забезпечила покращення водного режиму грунту за рахунок акумуляції осінньо-зимових опадів, про що ми вже зазначали. Крім того, за кращої структури грунту на глибині його обробітку, а саме за оранки зменшувались непродуктивні втрати вологи на стік та непродуктивне випаровування. Як наслідок, створюються більш сприятливі умови для росту й розвитку рослин ріпаку в осінній період, що забезпечує значний приріст урожайності порівняно 3 дискуванням на 12-14 см. Тобто вплив основного обробітку грунту на врожайність насіння ріпаку озимого, головним чином, залежить від природно-кліматичних умов у період вегетації культури, і значно менше від способу підготовки основного обробітку грунту.

Результатами досліджень встановлено, що строки сівби істотно впливали на насіннєву продуктивність ріпаку. Так, у середньому за роки досліджень, за сівби у I декаду вересня врожайність насіння склала 4,0 т/га. За сівби у II та III декади вересня вона знижувалась на $15,0 \%$ і 40,0\% та відповідно становила 3,4 т/га і 2,4 т/га (рис. 1). Таку ж закономірність встановлено і за роками досліджень.

Максимальну врожайність насіння у досліді - 4,3 т/га, незалежно від вивчаємих факторів, отримали за сівби у I декаду вересня у сприятливому за природно-кліматичними показниками 2015 році.

Погодні умови холодної пори 2012-2013 рр. виявилися надто складними для перезимівлі рослин ріпаку озимого. Як насідок, урожайність насіння на посівах останнього строку сівби знизилась в 1,7 рази порівняно із сівбою у I декаду вересня і склала 2,2 т/га. Для рослин за III 


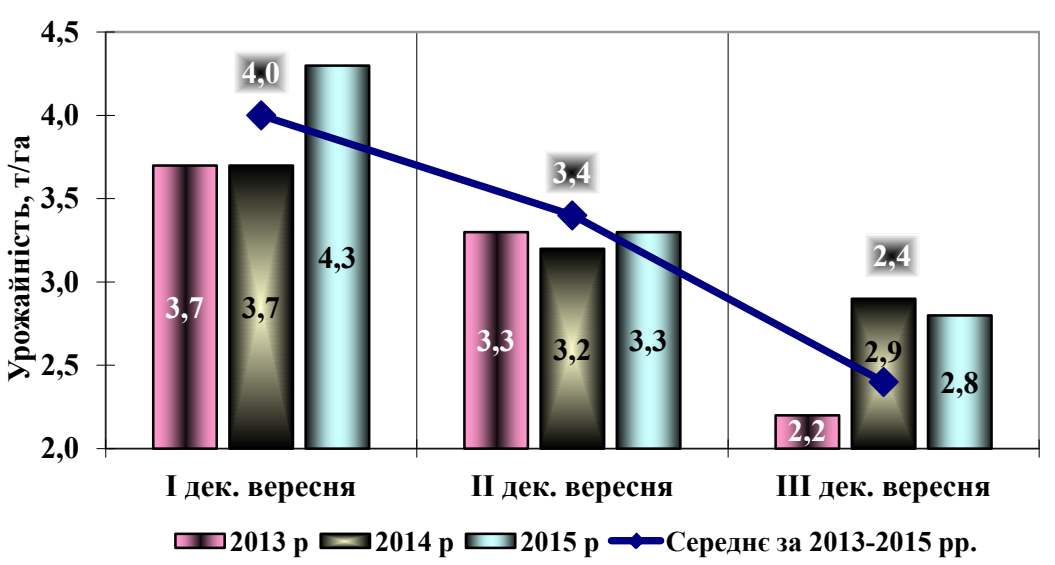

\section{Рис. 1. Урожайність насіння ріпаку озимого залежно від строку сівби}

строку сівби погодні умови осені виявилися несприятливими і перш за все за температурним режимом. Прохолодна погода з заморозками затримала розвиток рослин ріпаку в результаті чого вони на кінець листопада сформували 3,4-4,4 листки і діаметр кореневої шийки 1,7-2,3 мм, що було вкрай недостатнім для сприятливої перезимівлі.

Найсприятливіші умови для формування врожаю насіння ріпаку озимого створюються за умов, які найкраще відповідають потребам рослин. Відомо, що оптимізація густоти посіву й площі живлення рослин, бере початок із його просторового розміщення.

У середньому за роки досліджень із способів сівби, що вивчали, більш результативним виявився звичайний рядковий із шириною міжрядь 15 см, де середня врожайність склала 3,6 т/га та перевищила їі у широкорядних посівах з шириною міжрядь 30 см та 60 см відповідно на $11,1 \%$ і $16,7 \%$ (рис. 2 ).

Таким чином, досліджувані фактори є важливими у технології вирощування ріпаку озимого та значно впливають на врожайність. Так, найвищою - 4,54 т/га вона сформована за сівби ріпаку у I декаду вересня, 3 шириною міжрядь 15 см по фону оранки, проти 2,18 т/га за сівби у III декаду вересня, з шириною міжрядь 60 см та дискування на глибину 12-14 см (табл. 4). 


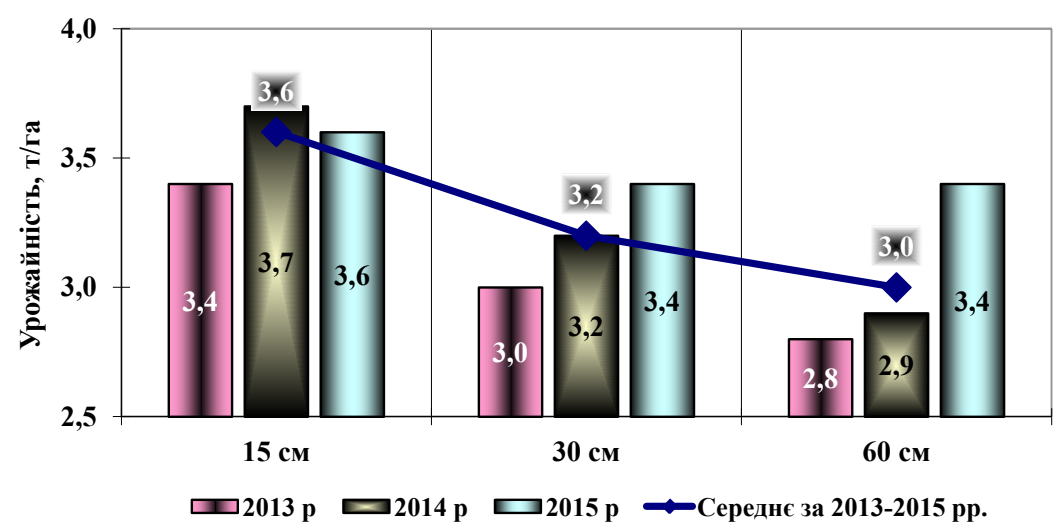

Рис. 2. Урожайність насіння ріпаку озимого залежно від способу сівби

Упродовж років проведення досліджень урожайність насіння ріпаку коливалася в межах від 1,77 до 5,02 т/га залежно від основного обробітку грунту, строку сівби, ширини міжрядь та погодних умов вегетаційного періоду.

Невід'ємною часткою при виконанні завдання щодо отримання високих урожаїв ріпаку озимого є покращення якості продукції. Останнім часом вимогливість до якості врожаю значно зросла.

Зумовлено це інтенсифікацією процесів у харчовій промисловості та тваринництві, забрудненням навколишнього середовища, запровадженням інтенсивних технологій вирощування польових культур, широким використанням хімічних речовин у сільському господарстві.

Основною метою при вирощуванні насіння ріпаку озимого на товарні цілі $є$ високий вміст у ньому олії. Вміст жиру в насінні ріпаку озимого коливався в межах від 41,7\%, у варіантах з поверхневим обробітком грунту за сівби у III декаду вересня з шириною міжрядь 60 см, до 45,5\% при оранці на 25-27 см за сівби у I декаду вересня звичайним рядковим способом (табл. 5).

Дослідженнями впливу основного обробітку грунту під сівбу ріпаку озимого встановлено, що оранка сприяла більш високому - 42,1-45,5\% вмісту жиру в насінні порівняно з дискуванням, де він коливався від $41,7 \%$ до $44,7 \%$. 
Таблиця 4

Урожайність ріпаку озимого

залежно від досліджуваних факторів, т/га

\begin{tabular}{|c|c|c|c|c|c|c|}
\hline \multirow{2}{*}{$\begin{array}{c}\text { Обробіток } \\
\text { грунту, А }\end{array}$} & \multirow{2}{*}{$\begin{array}{c}\text { Строк } \\
\text { сівби, В }\end{array}$} & \multirow{2}{*}{$\begin{array}{c}\text { Ширина } \\
\text { міжрядь, } \\
\text { см, С }\end{array}$} & \multicolumn{4}{|c|}{ Роки досліджень } \\
\hline & & & 2013 p. & 2014 p. & 2015 p. & Середнє \\
\hline \multirow{9}{*}{ 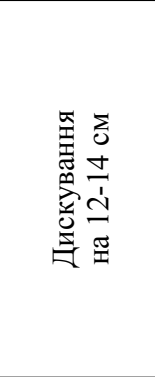 } & \multirow{3}{*}{$\begin{array}{l}\text { I дек. } \\
\text { вересня }\end{array}$} & 15 & 4,46 & 4,12 & 4,13 & 4,24 \\
\hline & & 30 & 3,86 & 3,65 & 3,84 & 3,78 \\
\hline & & 60 & 3,58 & 3,26 & 3,70 & 3,51 \\
\hline & \multirow{3}{*}{$\begin{array}{l}\text { II дек. } \\
\text { вересня }\end{array}$} & 15 & 3,72 & 3,80 & 3,10 & 3,54 \\
\hline & & 30 & 3,28 & 3,46 & 2,95 & 3,23 \\
\hline & & 60 & 3,12 & 3,02 & 2,81 & 2,98 \\
\hline & \multirow{3}{*}{$\begin{array}{l}\text { III дек. } \\
\text { вересня }\end{array}$} & 15 & 2,79 & 2,38 & 2,61 & 2,59 \\
\hline & & 30 & 2,38 & 2,05 & 2,51 & 2,31 \\
\hline & & 60 & 2,09 & 1,89 & 2,56 & 2,18 \\
\hline \multirow{9}{*}{ 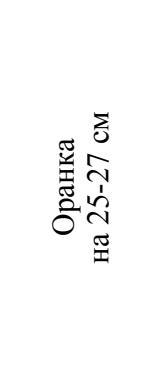 } & \multirow{3}{*}{$\begin{array}{l}\text { I дек. } \\
\text { вересня }\end{array}$} & 15 & 3,86 & 4,75 & 5,02 & 4,54 \\
\hline & & 30 & 3,42 & 4,12 & 4,57 & 4,04 \\
\hline & & 60 & 3,07 & 3,80 & 4,80 & 3,89 \\
\hline & \multirow{3}{*}{$\begin{array}{c}\text { II дек. } \\
\text { вересня }\end{array}$} & 15 & 3,58 & 3,96 & 3,70 & 3,74 \\
\hline & & 30 & 3,25 & 3,48 & 3,69 & 3,47 \\
\hline & & 60 & 2,85 & 3,32 & 3,66 & 3,28 \\
\hline & \multirow{3}{*}{$\begin{array}{l}\text { III дек. } \\
\text { вересня }\end{array}$} & 15 & 2,23 & 2,98 & 2,95 & 2,72 \\
\hline & & 30 & 1,94 & 2,53 & 3,04 & 2,50 \\
\hline & & 60 & 1,77 & 2,24 & 2,87 & 2,29 \\
\hline \multicolumn{7}{|c|}{ А. Оцінка істотності часткових відмінностей } \\
\hline \multirow{3}{*}{ HIP05 } & $\mathrm{A}=$ & & 0,07 & 0,05 & 0,05 & 0,08 \\
\hline & $\mathrm{B}=$ & & 0,11 & 0,04 & 0,12 & 0,05 \\
\hline & $\mathrm{C}=$ & & 0,08 & 0,04 & 0,05 & 0,04 \\
\hline
\end{tabular}

Більш чітко на олійність насіння ріпаку озимого впливали строки сівби. Із запізненням сівби вміст жиру знижувався від 44,2-45,5\% за сівби у I декаду вересня до 43,3-44,3\% у II декаду та 41,7-42,6\% у III декаду вересня. Отримані нами дані співпадають з результатами досліджень багатьох учених. Посіви ріпаку озимого в оптимальні строки довше вегетують і завдяки цьому накопичують більшу кількість сонячної радіації, яка в свою чергу є головним чинником у накопиченні жиру в насінні. 
Таблиця 5

Вміст жиру й протеїну у насінні ріпаку озимого та їх умовний збір залежно від досліджуваних факторів (середнє за 2013-2015 рр.)

\begin{tabular}{|c|c|c|c|c|c|c|}
\hline \multirow{2}{*}{$\begin{array}{c}\text { Обробіток } \\
\text { грунту, A }\end{array}$} & \multirow{2}{*}{$\begin{array}{c}\text { Строк } \\
\text { сівби, В }\end{array}$} & \multirow{2}{*}{$\begin{array}{c}\text { Ширина } \\
\text { міжрядь, } \\
\text { см, С }\end{array}$} & \multicolumn{2}{|c|}{ Вміст, \% } & \multicolumn{2}{|c|}{ Умовний збір, т/га } \\
\hline & & & жиру & $\begin{array}{c}\text { сирого } \\
\text { протеїну }\end{array}$ & олії & протеїну \\
\hline \multirow{9}{*}{ 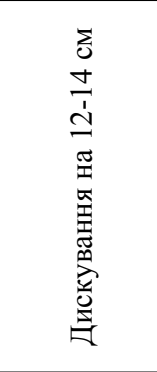 } & \multirow{3}{*}{$\begin{array}{c}\text { I дек. } \\
\text { вересня }\end{array}$} & 15 & 44,7 & 24,25 & 1,99 & 1,08 \\
\hline & & 30 & 44,5 & 24,44 & 1,75 & 0,96 \\
\hline & & 60 & 44,2 & 24,53 & 1,63 & 0,91 \\
\hline & \multirow{3}{*}{$\begin{array}{c}\text { II дек. } \\
\text { вересня }\end{array}$} & 15 & 44,2 & 24,27 & 1,59 & 0,87 \\
\hline & & 30 & 43,8 & 24,57 & 1,42 & 0,80 \\
\hline & & 60 & 43,8 & 24,63 & 1,35 & 0,76 \\
\hline & \multirow{3}{*}{$\begin{array}{c}\text { III дек. } \\
\text { вересня }\end{array}$} & 15 & 42,0 & 23,98 & 1,17 & 0,67 \\
\hline & & 30 & 42,1 & 24,07 & 1,04 & 0,60 \\
\hline & & 60 & 41,7 & 24,12 & 0,96 & 0,55 \\
\hline \multirow{9}{*}{ 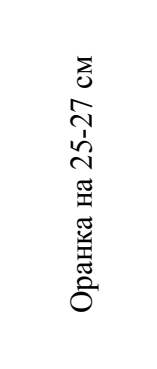 } & \multirow{3}{*}{$\begin{array}{c}\text { I дек. } \\
\text { вересня }\end{array}$} & 15 & 45,5 & 24,21 & 1,97 & 1,05 \\
\hline & & 30 & 45,0 & 24,32 & 1,75 & 0,94 \\
\hline & & 60 & 45,1 & 24,49 & 1,67 & 0,91 \\
\hline & \multirow{3}{*}{$\begin{array}{c}\text { II дек. } \\
\text { вересня }\end{array}$} & 15 & 44,3 & 24,12 & 1,64 & 0,89 \\
\hline & & 30 & 43,3 & 24,38 & 1,50 & 0,85 \\
\hline & & 60 & 43,7 & 24,41 & 1,39 & 0,78 \\
\hline & \multirow{3}{*}{$\begin{array}{l}\text { III дек. } \\
\text { вересня }\end{array}$} & 15 & 42,6 & 24,00 & 1,07 & 0,60 \\
\hline & & 30 & 42,2 & 24,16 & 0,99 & 0,57 \\
\hline & & 60 & 42,1 & 24,22 & 0,92 & 0,53 \\
\hline
\end{tabular}

Серед варіантів досліду, де вивчали ширину міжрядь, найбільшу тенденцію до збільшення олійності в насінні мали ділянки 3 шириною міжрядь 15 см. На цих посівах, у середньому за роки проведення досліджень, вміст жиру становив 42,0-45,5\% на відміну від 41,7-45,0\% за широкорядних способів сівби.

Насіння ріпаку озимого крім жиру, містить ще до 21-24\% сирого протеїну, а ріпакова макуха у сухій масі $37-43 \%$ протеїну, що робить ріпак джерелом кормового білка. Білок насіння ріпаку, крім того, багатий на сірчасті амінокислоти, які відсутні у складі білка бобових та зернових культур, тому при включенні цих компонентів до кормових сумішок можна отримати добрі результати при згодовуванні їх тваринам. За результатами досліджень чіткої закономірності у зміні вмісту 
сирого протеїну у насінні ріпаку нами не виявлено. Незалежно від досліджуваних факторів у середньому по варіантах, цей показник коливався в межах 23,98-24,63\%. Лише статистичним аналізом було визначено незначну закономірність до підвищення вмісту протеїну в насінні за більшої ширини міжрядь. Так, за сівби ріпаку озимого звичайним рядковим способом вміст сирого протеїну в насінні був на 0,26\% меншим порівняно з сівбою з шириною міжрядь 60 см (рис. 3).

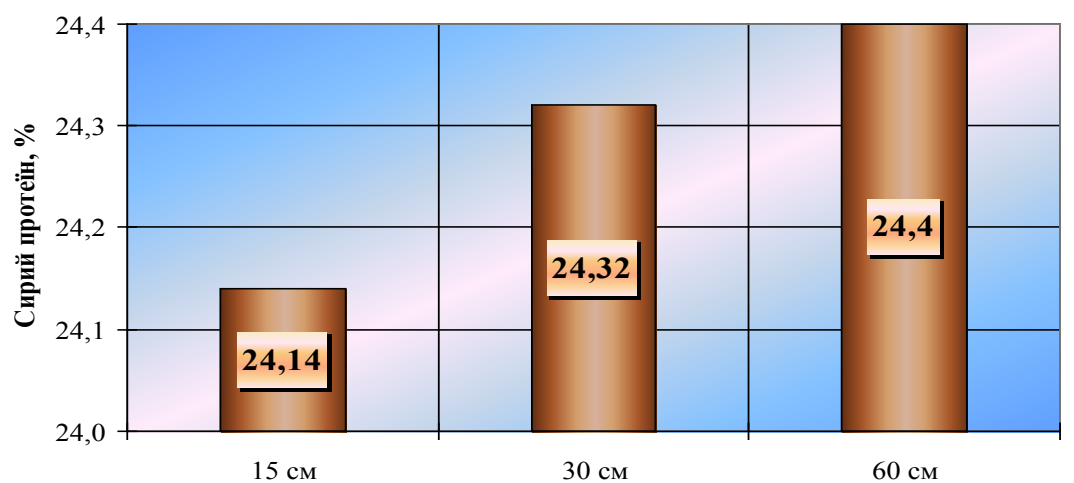

Рис. 3. Вміст сирого протеїну в насінні ріпаку озимого залежно від ширини міжрядь (середнє за 2013-2015 рр.), \%

Рівень урожаю насіння ріпаку і вміст у ньому олії та сирого протеїну забезпечують різний умовний їх вихід з 1 га посіву. Ці показники $\epsilon$ вираженням доцільності вирощування ріпаку озимого на насіння. Розрахувавши їх вихід з одиниці площі, можна більш детально аргументувати вплив досліджуваних факторів на ефективність вирощування. У середньому, за роки досліджень, найвища врожайність насіння ріпаку озимого - 4,54 т/га, сформована у варіанті з оранкою, де проводили сівбу у I декаду вересня звичайним рядковим способом з шириною міжрядь 15 см.

Найвищим вміст жиру визначений у насінні варіантів також 3 оранкою - 45,5\%. На вміст протеїну, який коливався в межах 24,0-24,6\%, досліджувані фактори суттєво не впливали. Максимальний умовний збір олії (1,97 т/га) і протеїну (1,05 т/га) отримали за сівби у I декаду вересня звичайним рядковим способом по фону оранки. 


\section{6. Висновки}

Дослідженнями, проведеними на чорноземі звичайному впродовж 2012-2015 рр. $з$ культурою ріпаку озимого сорту Чемпіон України, визначено, що спосіб основного обробітку грунту під цю культуру, а саме дискування на 12-14 см і традиційна оранка на 25-27 см, істотно впливають на окремі показники родючості чорнозему звичайного урожайність і якість насіння.

- Так, щільність складення грунту за визначення цього показника у шарах 0-10, 10-20, 20-30 і 0-30 см в основні періоди вегетації більш сприятливих параметрів для рослин досягала за проведення традиційної оранки на 25-27 см порівняно з дискуванням на глибину 12-14 см, за якого грунт ущільнюється більшою мірою й особливо у період завершення вегетації ріпаку озимого;

- Визначено, що оранка, внаслідок створення більш оптимальних агро-фізичних показників, забезпечує зростання вмісту в грунті рухомого азоту-нітратів упродовж росту і розвитку рослин за максимальної їх кількості у фазу розетки з поступовим зменшенням до періоду завершення вегетації.

- Вміст рухомого фосфору в досліджуваному шарі грунту 0-50 см, більшим визначений також по фону проведення оранки. Проте для верхнього 0-10 см шару грунту більший вміст цього елементу живлення забезпечило дискування на 12-14 см порівняно з оранкою. До збирання врожаю ріпаку озимого вміст Р2O5 у грунті у грунті по обох фонах його обробітку вирівнюється, тобто зазначена різниця навіть для поверхневого шару грунту згладжується.

- Визначено, що врожайність насіння ріпаку озимого залежала i змінювалася під впливом усіх досліджуваних факторів: способу основного обробітку грунту, строку сівби, ширини міжрядь і дуже істотно різнилася від умов вегетаційного періоду рослин і кількості накопиченої грунтом вологи на початок сівби. У роки досліджень залежно від прийнятих на вивчення елементів технології вона коливалася в межах від 1,77 до 5,02 т/га.

- Максимальною врожайність насіння незалежно від умов року формується за сівби у I декаду вересня з шириною міжрядь 15 см по фону оранки. У цьому варіанті у середньому за три роки вона склала 4,24 т/га, що перевищує цей показник за III строку сівби з міжряд- 
дями 60 см на 43,7\% (за рівня врожайності у останньому варіанті лише $2,29 \mathrm{~T} /$ га).

- Якість насіння ріпаку озимого також найкращих показників досягла за проведення оранки, сівби у I декаду вересня і ширини міжрядь 15 см. При цьому в насінні найбільше містилося жиру та сирого протеїну і максимальним був їх умовний збір з гектару: 1,99 т/ га олії та 1,08 т/га протеїну.

- Таким чином за вирощування ріпаку озимого в умовах Південного Лісостепу України за сучасних змін клімату найбільш доцільно у якості основного обробітку грунту проводити оранку на 25-27 см, сівбу проводити у I декаді вересня з шириною міжрядь 15 см. За таких умов урожайність насіння формується на рівні більше 4,0 т/га 3 високими показниками його якості - вмістом жиру і сирого протеїну, за умовного їх збору з одиниці площі на рівні 2 та 1 т/га відповідно.

- Дослідження у даному напрямі доцільно продовжувати, адже змінюються умови господарювання, відбуваються грунтово-кліматичні зміни, з'являються нові сорти та гібриди.

\section{Список літератури:}

1. Гамаюнова В.В. Ефективність зрошення та вплив добрив на використання вологи рослинами і підвищення стійкості землеробства зони Степу. «Адаптація агротехнологій до змін клімату: грунтово-агрохімічні аспекти» : монографія / С.А. Балюк, В.В. Медведєв, Б.С. Носка. Харків, 2018. 364 с.

2. Hamajunova U., Hlushko T., Honenko L. Presevation of soil fertility as a basis for improving the efficiency of management in the southern Steppe of Ukraine. Scientific development and achievements-Sciemcee (publishing London). London, 2018. Volume 4. P. 13-27.

3. Гордієнко В.П. Мінімалізація обробітку грунту в польовій сівозміні. Збірник наукових праць, присвячений 100-річчю з дня народження С.С. Рубіна. Умань: УСГА, 2000. 464 с.

4. ДержиР.Ситуація ізприродоохоронним землеробствому світі. Міжнародна конференція з технології NO-Till-n. Ювілейний випуск, 2004. С. 141-144.

5. Chang C., Lindwall W. Effect of long-term minimum tillage practices on some physical properties of a chernozemic clayloam. Canad. I. Soil Sc., 1989. P. 443-449.

6. Ревут И.Б., Соколовская И.А., Васильев А.М. Структура и плотность почвы - основные параметры кондиционирующие почвенные условия жизни растений. Л.: Гидрометеоиздат, 1971. С. 54-125.

7. Гордієнко В.П., Бодня В.І. Вплив тривалого застосування різних систем удобрення у обробітку грунту в сівозміні на урожайність ярого 
ячменю. Наукові праці Полтавської державної аграрної академії. 2005. №4 (23). C. 94-100.

8. Сайко В.Ф., Малієнко А.М. Системи обробітку грунту в Україні. Київ : ВД «ЕМКО», 2007. $44 \mathrm{c}$.

9. Цилюрік О.І. Вплив мульчувального обробітку на поживний режим чорнозему в посівах ячменю ярого. Вісник Дніпропетровського аграрно-економічного університету. 2017. № 3(45). С. 23-31.

10. Małecka, I., Blecharczyk, A., Sawinska, Z., Dobrzeniecki, T. The effect of various long-term tillage systems on soil properties and spring barley yield. Turkish Journal of Agriculture and Forestry. 2012. 36, 217-226. doi: 10.3906/tar-1104-20

11. Камінська В.В., Дудка О.Ф., Мушик Б.В. Продуктивність ячменю ярого за різних технологій вирощування. Збірник наукових пращь Національного наукового иентру «Інститут землеробства НААН». 2016. № 3-4. С. 115-121.

12. Bogužas V., Sinkevičienė A., Romaneckas K., Steponavičienè V., Butkevičienè L. M. The impact of tillage intensity and meteorological conditions on soil temperature, moisture content and $\mathrm{CO}_{2}$ efflux in maize and spring barley cultivation. Zemdirbyste-Agriculture. 2018, 307-314. doi: 10.13080/z-a. 2018.105.039

13. Конишев А.А., Конишева Е.Х. Погодные условия и выбор обработки почвы. Земледелие. 2007. С. 6-12.

14. Цилюрік O.I., Шапка В.П. Ефективність безполицевого обробітку грунту за вирощування ячменю ярого в Північному Степу. Вісник Полтавської державної аграрної академії. 2014. № 1. С. 25-29.

15. Кифорук I. Захист посівів ріпаку від бур'янів. Агроном. 2011. № 1. C. $124-125$.

16. Майсурян А.С. Агробактеріальна трансформація насіння ріпаку (Brassica napus L.). Біологія рослинних клітин in vitro та біотехнологія: тези IX Міжнародної конференції. Звенигород, Москва: ФБК-прес. 2008. Вип. 123. C. $112-224$.

17. Проценко B.I. Шляхи підвищення врожаю озимого ріпаку в північно-східному лісостепу України. Літописи Сумського національного аграрного університету: серія «Агрономія та біологія». Питання. 2014. № 3(27). C. 175-178.

18. Пілюк Я.Є., Белавський В.М. Особливі аспекти вирощування озимого ріпаку. Сучасні технології рослинництва в Білорусі. Мінськ: Міністерство фінансів ІВЦ, 2005. С. 134-46.

19. Примак І.Д., Панченко О.Б. Вплив механічного обробітку грунту та удобрення у спеціалізованій зернопросапній сівозміні Центрального Лісостепу України на агрофізичні властивості чорнозему типового. Наукові доповіді Національного університету біоресурсів $і$ природокористування Украӥни. 2015. № 6. URL: http://nbuv.gov.ua/UJRN/Nd_2015_6_11

20. Погромська Я. Вплив систем удобрення на забезпеченість чорнозему звичайного рухомими формами NPK залежно від способів його обробітку. Вісник Львівського національного аграрного університету. Агрономія. 2019. № 23. C. 212-221. https://doi.org/10.31734/agronomy2019.01.212 
21. Шувар I.А., Гудзь В.П., Печенюк В.І., Камінський В.Ф., Юркевич С.О., Бойко І.Є. Обробіток грунту в адаптивно-ландшафтних системах землеробства. Навчальний посібник. Львів, 2011. 381 с.

22. Дегтярьов В.В. Охорона і відновлення родючості грунтів. Цикл лекцій для студентів освітнього ступеня «магістр» спеціальності 201 «Агрономія». Харків, 2017. 257 с.

23. Лихочвор В.В., Проць Р.Р. Ріпак. Підручник. Львів : НВФ Українські технології, 2005. $88 \mathrm{c}$.

24. Гамаюнова В.В., Коваленко О.А., Хоненко Л.Г. Сучасні підходи до ведення землеробської галузі на засадах біологізації та ресурсозбереження. (за редакцією П.В. Писаренка, Т.О. Чайки, І.О. Яснолоб) : колективна монографія. Полтава: ПДАА, 2018. 324 с.

\section{References:}

1. Gamayunova, V.V. (2018). Efektyvnist zroshennia ta vplyv dobryv na vykorystannia volohy roslynamy i pidvyshchennia stiikosti zemlerobstva zony Stepu [Irrigation efficiency and influence of fertilizers on the use of moisture by plants and increasing the sustainability of agriculture in the steppe zone]. Monohrafiia "Adaptatsiia ahrotekhnolohii do zmin klimatu: hruntovo-ahrokhimichni aspekty» (za naukovoiu redaktsiieiu S.A. Baliuka, V.V. Medvedieva, B.S. Noska). Kharkiv: Stylna typohrafiia, $364 \mathrm{p}$.

2. Gamayunova, U., Glushko, T., Honenko, L. (2018). Presevation of soil fertility as a basis for improving the efficiency of management in the southern Steppe of Ukraine. Scientific development and achievements-Sciemcee (publishing London), 4, 13-27.

3. Gordienko, V.P. (2000). Minimalizatsiia obrobitku gruntu v polovii sivozmini [Minimization of tillage in field crop rotation]. Zbirnyk naukovykh prats, prysviachenyi 100-richchiu z dnia narodzhennia S.S. Rubina.

4. Derzhy, R. (2004). Sytuatsiia iz pryrodookhoronnym zemlerobstvom u sviti [The situation with conservation agriculture in the world]. Teza dopovidei Mizhnarodnoi konferentsii $z$ tekhnolohii NO-Till-n (Yuvileinyi vypusk), pp. 141-144.

5. Chang, C., Lindwall, W. (1989). Effect of long-term minimum tillage practices on some physical properties of a chernozemic clayloam. Canad. I. Soil Sc., pp. 443-449.

6. Revut, Y.B., Sokolovskaia, Y.A., Vasylev, A.M. (1971). Struktura y plotnost pochvy - osnovnye parametry kondytsyonyruiushchye pochvennye uslovyia zhyzny rastenyi [Soil structure and density-the main parameters of soil conditioning conditions of plant life]. L.: Hydrometeoyzdat, pp. 54-125.

7. Gordienko, V.P., Bodnya, V.I. (2005). Vpliv trivalogo zastosuvannya riznih sistem udobrennya y obrobitku gruntu v sivozmini na urozhaynist yarogo yachmenyu [Influence of prolonged use of different fertilizer systems and tillage in crop rotation on spring barley yield]. Naukovi pratsi Poltavskoyi derzhavnoyi agrarnoyi akademiyi, 4(23), 94-100. 
8. Sayko, V.F., MaliEnko, A.M. (2007). Sistemi obrobitku Gruntu v Ukrayini [Soil tillage systems in Ukraine]. Kiyiv : VD «EMKO», 44. (in Ukrainian)

9. Tsilyurik, O.I. (2017). Vpliv mulchuvalnogo obrobitku gruntu na pozhivniy rezhim chornozemu v posivah yachmenyu yarogo [Influence of mulching tillage on the nutrient regime of black soil in spring barley crops]. Visnik Dnipropetrovskogo agrarno-ekonomichnogo universitetu, 3(45), 23-31. (in Ukrainian)

10. Małecka, I., Blecharczyk, A., Sawinska, Z., Dobrzeniecki, T. (2012). The effect of various long-term tillage systems on soil properties and spring barley yield. Turkish Journal of Agriculture and Forestry, 36, 217-226. doi: 10.3906/tar-1104-20

11. Kaminska, V.V., Dudka, O.F., Mushik, B.V. (2016). Produktivnist yachmenyu yarogo za riznih tehnologly viroschuvannya [Spring barley productivity with different growing technologies]. Zbirnik naukovih prats Natsionalnogo naukovogo tsentru «Institut zemlerobstva NAAN», 3-4, 115-121. (in Ukrainian)

12. Bogužas, V., Sinkevičienè, A., Romaneckas, K., Steponavičienė, V., Butkevičienè, L.M. (2018). The impact of tillage intensity and meteorological conditions on soil temperature, moisture content and $\mathrm{CO}_{2}$ efflux in maize and spring barley cultivation. Zemdirbyste-Agriculture, 105, 4, 307-314. doi 10.13080/z-a.2018.105.039

13. Konishhev, A.A., Konishheva, E.H. (2007). Pogodnye uslovija i vybor obrabotki pochvy [Weather conditions and choice of tillage]. Zemledelie, 6, 12. (in Russian)

14. Tsilyurik, O.I., Shapka, V.P. (2014). Efektivnist bezpolitsevogo obrobitku gruntu za viroschuvannya yachmenyu yarogo v pivnichnomu Stepu [Effectiveness of moldboardless tillage at spring barley cultivation in the Northern Steppe]. Visnik Poltavskoyi derzhavnoyi agrarnoyi akademiyi, 1, 25-29. (in Ukrainian)

15. Kyforuk, I. (2011). Zakhyst posiviv ripaku vid bur'ianiv [Protection of rape crops from weeds]. Ahronom, no. 1, pp. 124-125.

16. Maisurian, A.S. (2008). Ahrobakterialna transformatsiia nasinnia ripaku (Brassica napus L.) [Agrobacterium-mediated transformation of rapeseed (Brassica napus L.)]. Biolohiia roslynnykh klityn in vitro ta biotekhnolohiia: tezy IX Mizhnarodnoi konferentsii. Zvenyhorod, Moskva: FBK-pres. Vyp. 123, pp. 112-224.

17. Protsenko, V.I. (2014). Shliakhy pidvyshchennia vrozhaiu ozymoho ripaku v pivnichno-skhidnomu lisostepu Ukrainy [Ways to increase the yield of winter rape in the North-Eastern forest-steppe of Ukraine]. Litopysy Sumskoho natsionalnoho ahrarnoho universytetu. Seriia «Ahronomiia ta biolohiia». Issue 3(27). pp. 175-178.

18. Piliuk, Ya.Ye. (2005). Osoblyvi aspekty vyroshchuvannia ozymoho ripaku [Special aspects of winter rape cultivation]. Suchasni tekhnolohii roslynnytstva $v$ Bilorusi. Minsk: Ministerstvo finansiv IVTs, pp. 134-146.

19. Prymak, I.D., Panchenko, O.B. (2015). Vplyv mekhanichnoho obrobitku hruntu ta udobrennia u spetsializovanii zernoprosapnii sivozmini Tsentralnoho Lisostepu Ukrainy na ahrofizychni vlastyvosti chornozemu typovoho [The influence of mechanical soil treatment and fertilizer in a specialized grain crop rotation of the Central forest-Steppe of Ukraine on the agrophysical properties of typical Chernozem]. Naukovi dopovidi Natsionalnoho universytetu bioresursiv i pryrodokorystuvannia Ukrainy, no. 6. Available: http://nbuv.gov.ua/UJRN/Nd_2015_6_11

20. Pohromska, Ya. (2019). Vplyv system udobrennia na zabezpechenist chornozemu zvychainoho rukhomymy formamy NPK zalezhno vid sposobiv yoho 
obrobitku [Influence of fertilizer systems on the provision of ordinary Chernozem with mobile forms of NPK depending on the methods of its processing]. Visnyk Lvivskoho natsion. ahrarnoho universytetu. Ahronomiia. 23, 212-221. (in Ukrainian)

21. Shuvar, I.A., Hudz, V.P., Pecheniuk, V.I., Kaminskyi, V.F., Yurkevych, Ye.O., Boiko, I.Ye. (2011). Obrobitok hruntu v adaptyvno-landshaftnykh systemakh zemlerobstva [Soil treatment in adaptive landscape systems of agriculture]. Navchalnyi posibnyk. Lviv, 381. (in Ukrainian)

22. Dehtiarov, V.V. (2017). Okhorona $i$ vidnovlennia rodiuchosti hruntiv [Protection and restoration of soil fertility]. Tsykl lektsii dlia studentiv osvitnoho stupenia «mahistr» spetsialnosti 201 «Ahronomiia». Kharkiv, 257. (in Ukrainian)

23. Lykhochvor, V.V., Prots, R.R. (2005). Ripak [Rape]. Lviv: NVF Ukrainski tekhnolohii, 88. (in Ukrainian)

24. Gamayunova, V.V., Kovalenko, O.A., Honenko, L.G. (2018). Suchasni pidkhody do vedennia zemlerobskoi haluzi na zasadakh biolohizatsii ta resursozberezhennia [Modern approaches to the management of the agricultural sector on the principles of biologization and resource conservation]. Kolektyvna monohrafiia za redaktsiieiu P.V. Pysarenka, T.O. Chaiky, I.O. Yasnolob. Poltava: PDAA, 324. 